\title{
Vanamea GEN. NOV. FOR Livoneca symmetrica VAN NAME,1925, (CRUSTACEA, ISOPODA, CYMOTHOIDAE) AND A REDESCRIPTION OF THE SPECIES BASED ON SPECIMENS FROM BRAZILIAN PIRANHAS
}

\author{
Vernon E. THATCHER
}

\begin{abstract}
Studies of the cymothoid isopod Livoneca symmetrica Van Name, 1925, showed that this species has characters that preclude its inclusion in Livoneca Leach, 1818, or in any other known genus. The species is redescribed on the basis of male and female specimens from the mouth cavities of Amazonian piranhas (Serrasalmus spilopleura (Kner) and $S$ elongatus Kner) and Vanamea gen. nov. is proposed for it. The new genus is defined as having: a cephalon that is not immersed in pereonite 1; mandibles that are "foot-shaped" and without incisors; pereopods that are long and unequal in size and shape; a pleon that is not immersed in the pereon; and a pleotelson that is inflated anteriorly and medially.
\end{abstract}

Key words: Isopod, Cymothoid, Parasite, Piranha, Amazon.

Vanamea gen. nov, para Livoneca symmetrica Van Name, 1925, (Crustacea, Isopoda, Cymothoidae) e Uma Redescrição da Espécie com Base em Especimes de Pirahas Brasileiras

RESUMO - Estudos do isopode Cymothoidae, Livoneca symmetrica Van Name, 1925, mostraram que esta espécie tem caracteres que impossibilitam sua inclusão em Livoneca Leach, 1815 , ou em qualquer outro gênero conhecido. A espécie é redescrita na base de machos e fêmeas provenientes das cavidades bucais de piranhas amazônicas (Serrasalmus spilopleura (Kner) e $S$. elongatus Kner) e Vanamea gen. nov. é proposto para ela. O novo gênero define-se por apresentar: um cefalón não envolvido pelo primeiro pereonito; mandibulas com a "forma de pé" e sem incisores; pereópodos compridos e desiguais em tamanho e forma; um pleon não envolvido pelo último pereonito; e um pleotelso inflado anterior e medialmente.

Palavras-chave: Isopode, Cymathoidae, Parasita, Piranha, Amazônia.

\section{INTRODUCTION}

At least four genera of parasitic isopods (Cymothoidae) occur in piranhas (Serrasalmus spp.: Serrasalmidae). Those from the mouths of Brazilian piranhas are: Asotana magnifica described by THATCHER (1988) from Roraima, Brazil, and Livoneca symmetrica characterized by VAN NAME (1925) from Guyana.
The other two genera are from the gill chambers and are still under study.

According to TRILLES (1973), the species $L$. symmetrica is found in Guyana, Venezuela and Brazil and it invades at least seven host species. In spite of the fact that there are several published reports, no adequate description of this species exists. Thepresent paper seeks to provide one.

A study by BRUCE (1990) has

1 Instituto Nacional de Pesquisas da Amazônia, Coordenação de Pesquisas em Biologia Aquática, Caixa Postal 478, 69011-970, Manaus, Amazonas, Brasil. 
shown that $L$. symmetrica does not belong to Livoneca (= Lironeca) or to Ichthyoxenus Herklots, 1870. The detailed description given in the present work indicates that this species does not belong to any known genus. Vanamea gen. nov. is herein proposed to include this species.

\section{MATERIAL AND METHODS}

The methods used were those explained in THATCHER and CARVALHO (1988). Measurements are in millimeters $(\mathrm{mm})$ or micrometers (um).

Isopoda

Cymothoidae

VANAMEA gen. nov.

Generic diagnosis:

Female: Body elongate, symmetrical; pereon weakly vaulted, sides nearly parallel. Cephalon not immersed in pereonite 1 ; posterior margin not trisinuate. Coxae small, not surpassing posterior margins of respective pereonites. Pleon not immersed in pereonite 7 , only slightly narrower than pereon; pleonites subequal in length; pleopods laminate, with lateral laminar lobes on peduncles.

Antennule shorter than antenna; antennal bases set wide apart. Mouthparts: mandible "foot-shaped" without incisor; maxillule with 3 terminal and 2 subterminal recurved spines; maxilla bilobed with 2-3 recurved spines on each lobe; maxillipedal palp with 1 terminal and 1 subterminal recurved spine. Pereopods increasing in length from 1-7, without basipodal carinae; largest dactyls on pereopods $5-6$, smallest on 7.

Male: Body similar to that of female but smaller and less vaulted. Both sexes with pleotelson inflated anteriorly and medially.

Type species:

Vanamea symmetrica Van Name, 1925.

Vanamea symmetrica (Van Name, 1925)

(Figs. 1-30)

Hosts (from VAN NAME, 1925): Myloplus (= Myleus) rubripennis; Serrasalmo (= Serrasalmus) rhombeus; Branchyplatystoma sp; Hemidoras carinatus; and Cichla ocellaris. Additional hosts (from TRILLES, 1973): Vandelia cirrhosa and Carnegiella strigata. Other hosts (this paper): Serrasalmus spilopleura (Kner) and $S$. elongatus Kner.

Site: Mouth cavity (These parasites cling to the top of the host's tongue with their heads near the entrance of the fish's esophagus).

Geographic distribution (From TRILLES, 1973): Kartabo, Guyana; Tocantins and Araguaia Rivers, Pará, Brazil; Quebrada Honda River, near Zaraza, Venezuela. Other localities (this paper): Rei and Salgado Lakes, near Manaus, Amazonas, Brazil.

Specimens deposited: 6 females and 2 males; Invertebrate Collection, Instituto Nacional de Pesquisas da Amazônia (INPA), Manaus, AM, Brazil; (INPA-CR-645a-h): 1 female and 1 male. San Diego Natural History Museum, San Diego, California; 1 fe- 
male (USNM 250452), Smithsonian Institution, Washington, D.C.

Etymology: The generic name is in honor of the original author ofthe species.

\section{Species dianosis}

(based on 9 females and 4 males; measurements in Table 1).

Female (Figs. 1-3): body 2.3-3.3 times longer than wide, white or straw colored with scattered black chromatophores. Cephalon (Figs. 9,11) not immersed in pereonite 1 ; frontal margin blunt, undulating, somewhat depressed downward. Eyes prominent, black, ovoid. Antennule (Fig. 12) slightly compressed laterally, composed of 8 articles; antenna (Fig. 13) with 9 articles, reaching to just beyond eye.

Mouthparts (Figs. 14 and 17-20); labrum projecting forward, not folding under mandibles; mandibles "footshaped" without incisors; labium with lobes attached to mandibles; maxillule with 3 terminal and 2 subterminal recurved spines; maxilla bilobed with 23 spines on outer lobe and 2 on inner lobe; maxillipedal palp with 2 recurved

Table 1. Measurements ( $\mathrm{mm}$ ) of 4 males and 9 females of Vanamea symmetrica

\begin{tabular}{lllll}
\hline Sex & \multicolumn{2}{c}{ Body } & \multicolumn{2}{c}{ Pleotelson } \\
& L & W & L & W \\
\hline Males & 14 & 5 & 4 & 5 \\
& 16 & 5 & 4 & 4.5 \\
& 17 & 6 & 4 & 5 \\
Females & 18 & 6.5 & 4 & 5 \\
& 18 & 6 & 3.5 & 4 \\
& 18 & 7 & - & - \\
& 20 & 6 & 4.5 & 5 \\
& 20 & 8 & 4.5 & 5 \\
& 22.5 & 9 & 5 & 6 \\
& 23 & 8.5 & 4.5 & 5 \\
& 24 & 10.5 & 5.5 & 7 \\
& 26 & 11 & 7 & 8
\end{tabular}
dactyl 7 smaller than others. Basipods of pereopods without carinae,

Pleon (Fig. 10): pleonite I not immersed in pereonite 7 but coxae of latter overlap slightly the first pleonite; lateral lobes of pleonites curved ventrally. Pleopods (Figs. 2I-25) subequal, laminar, with lateral lobes on peduncles. Uropods (Fig. 28) with ovoid rami, exopod longer than endopod, provided with a few setae on medial margin. Pleotelson (Fig. 10) somewhat wider than long, inflated anteriorly and medially.

Male (Figs. 4-7) similar to female, but smaller. Body 2.3-3.2 times longer than wide.

\section{DISCUSSION}

In his revision of Livoneca, BRUCE (1990) removed $L$. symmetrica and more than 80 other nominal species from the genus on morphological grounds. The same author was unable to assign this species to genus but stated that it does not belong to Ichthyoxenus Herklots, 1870 , either. 


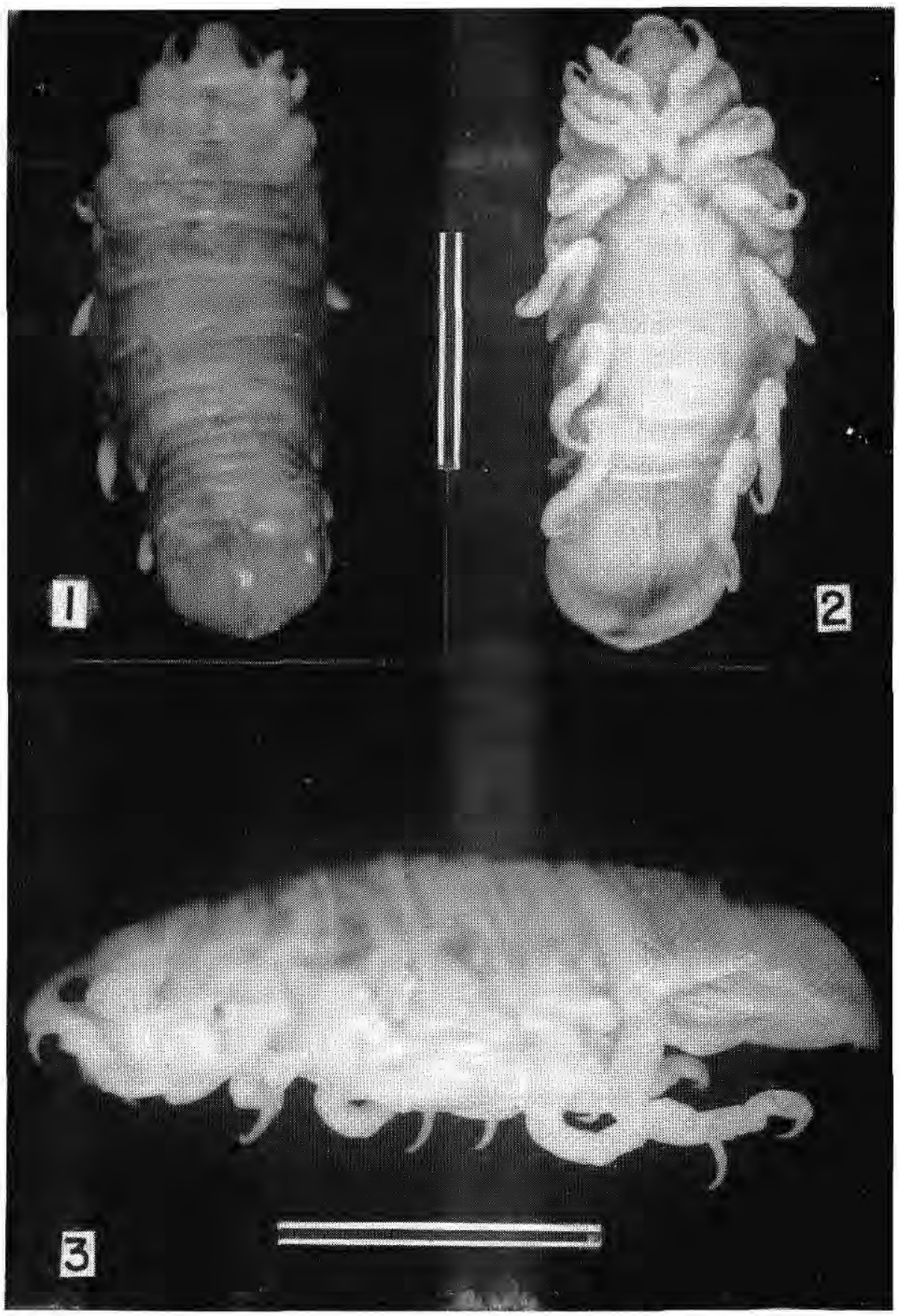

Figuras 1-3. Vanamea symmetrica (female). 1. Dorsal view. 2. Ventral view. 3 Lateral view. Scales $=10 \mathrm{~mm}$. 


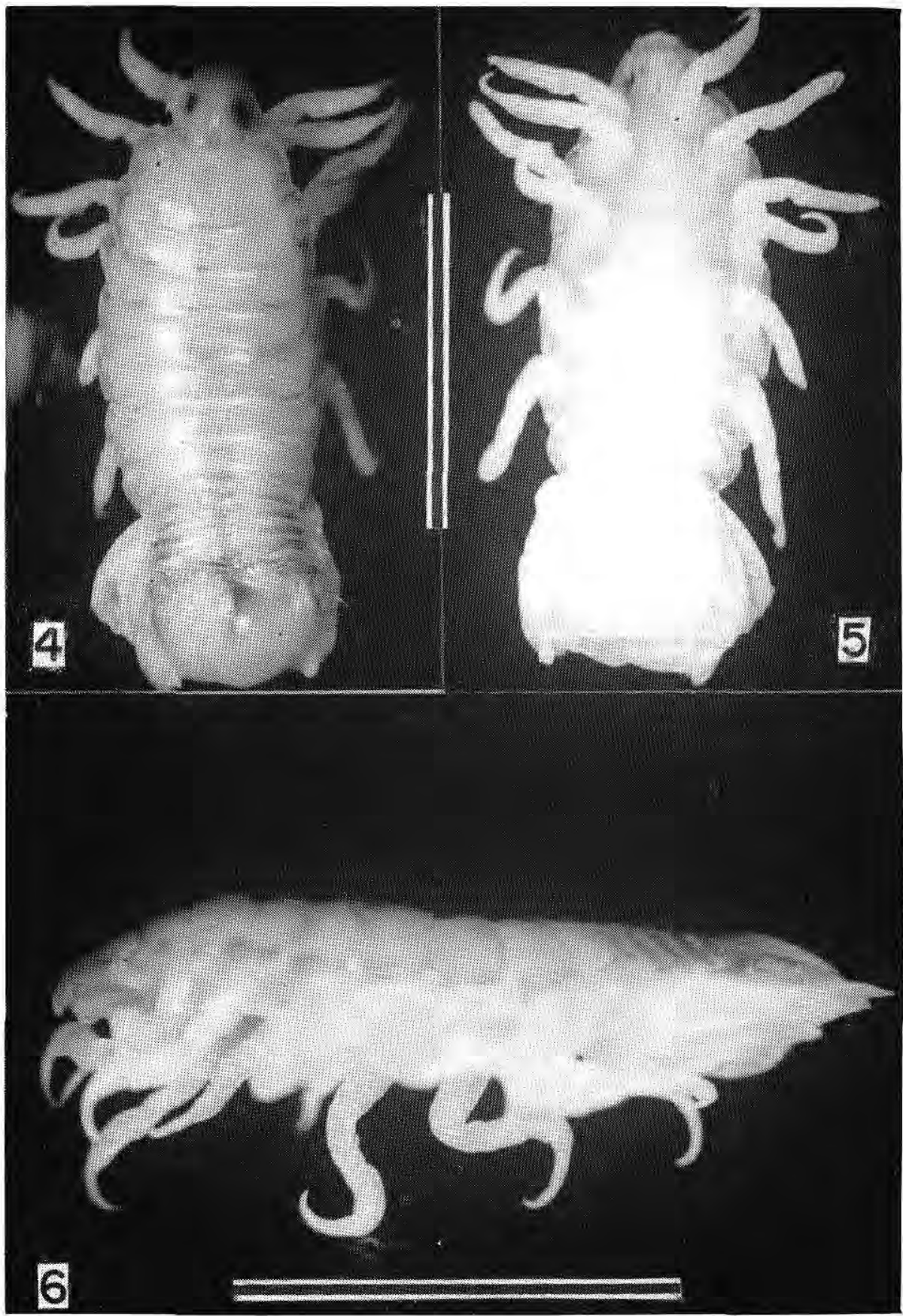

Figuras 4-6. Vanamea symmetrica (male). 4. Dorsal view. 5. Ventral view. 6. Lateral view. Scales $=10 \mathrm{~mm}$ 


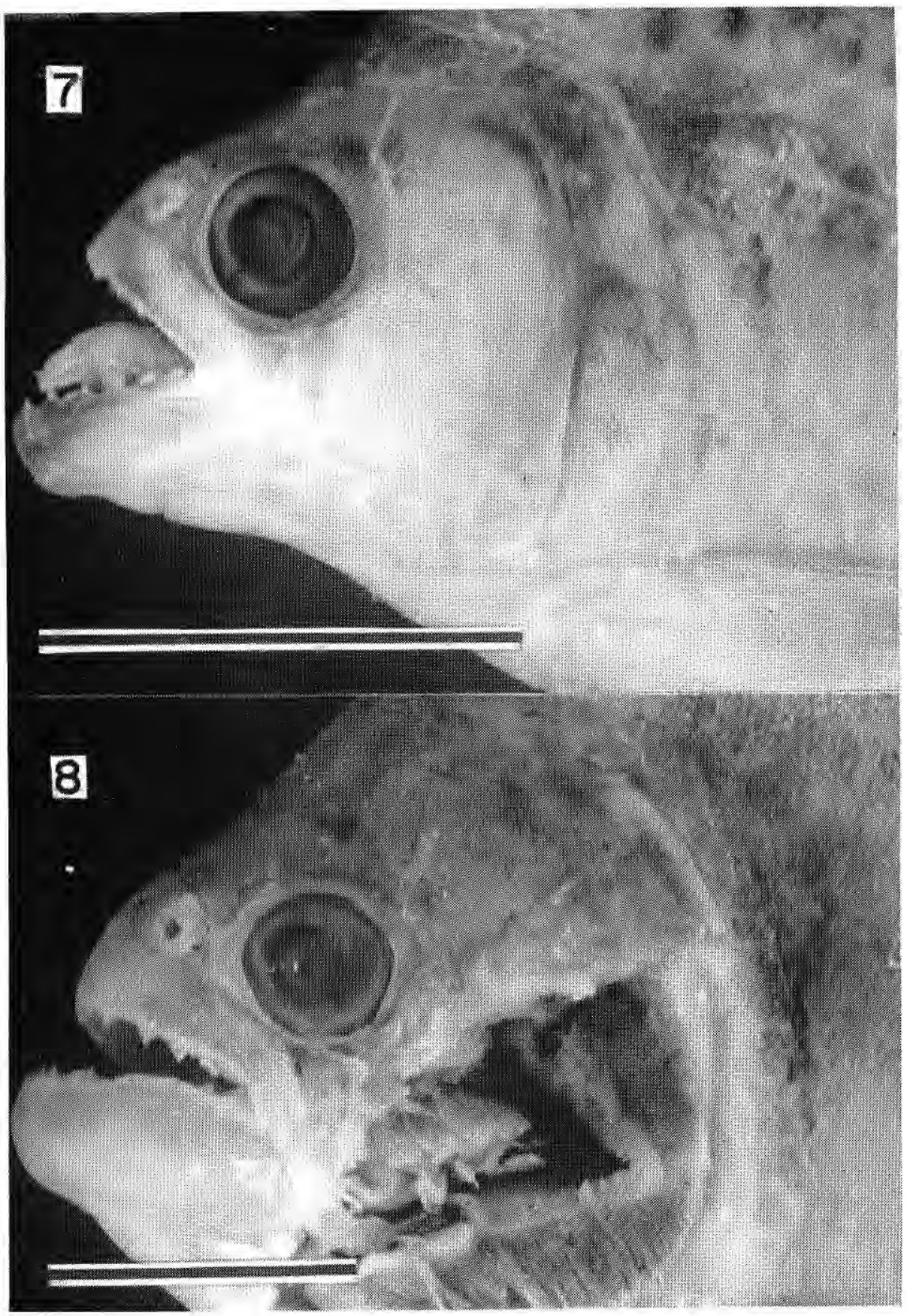

Figuras 7-8. Vanamea symmetrica in mouths of Serrasalmus spilopleura. 7. Male. 8 Female (operculum removed from host). Scales $=20 \mathrm{~mm}$. 


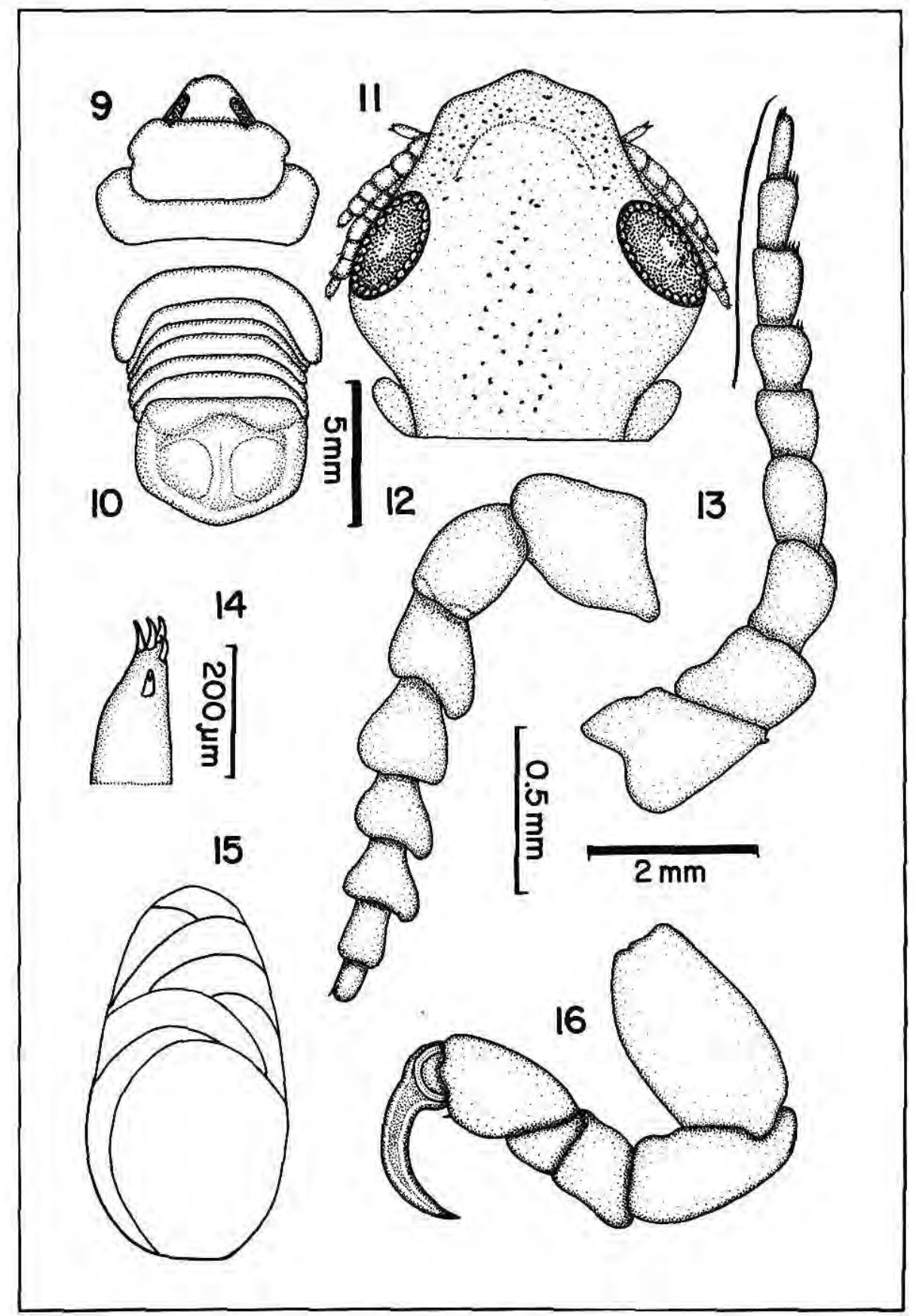

Figuras 9-16. Vanamea symmetrica (female). 9. Anterior end. 10. Pleon. 11. Cephalon. 12. Antennule. 13. Antenna. 14. Tip of maxillule. 15. Marsupium. 16. Pereopod 1. 


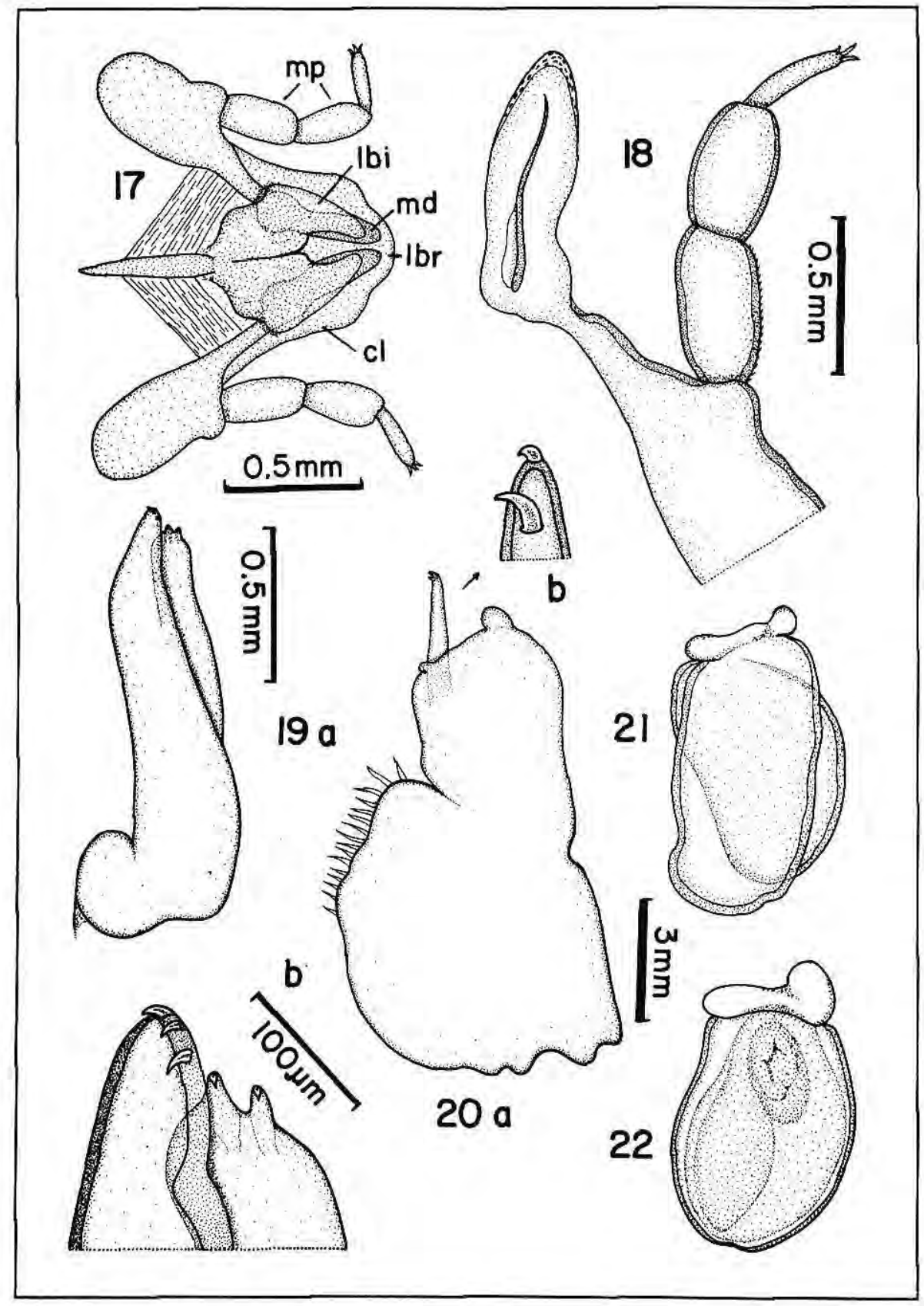

Figuras 17-22. Vanamea symmetrica (Female). 17. Mouthparts: $\mathrm{cl}=$ clypeus: $\mathrm{thi}=$ labium: $\mathrm{lbr}=$ labrum, $\mathrm{md}=$ mandible; $\mathrm{mp}=$ mandibular palp. 18 . Mandible with palp. 19a. Maxilla: 19b. Tip of maxilla; 20a. Maxilliped; 20b. Tip of maxillipedal palp. 21. Pleopod 1. 22. Pleopod 2 . 


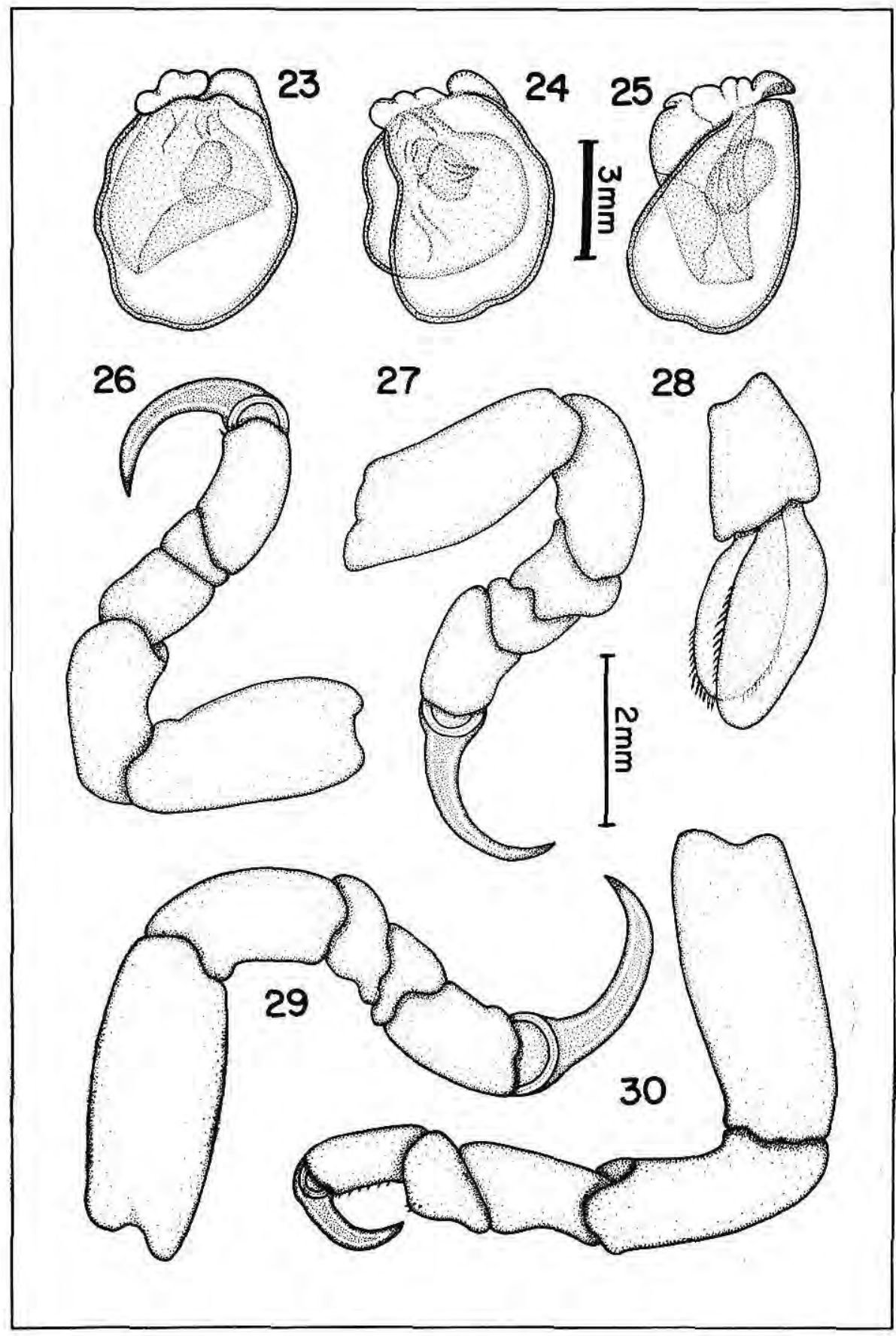

Figuras 23-30. Vanamea symmetrica (female). 23. Pleopod 3. 24. Pleopod 4. 25. Pleopod 5. 26. Pereopod 2. 27. Pereopod 3. 28. Uropod. 29. Pereopod 6. 30. Pereopod 7. 
The species Vanamea symmetrica can be distinguished from all known marine genera by the mandibular morphology and from the freshwater genera by body shape, the elongate pereopods and the inflated pleotelson.

\section{Literature Cited}

BRUCE, N. L. 1990. The genera Catoeessa, Elthusa, Enispa, Ichthyoxenus, Idusa, Livoneca and Norileca n. gen. (Isopoda, Cymothoidae), crustacean parasites of marine fishes, with descriptions of Eastern Australian species. Rec. Australian Mus., 42: 247-300.
THATCHER, V. E. 1988. Asotana magnifica n. sp. (Isopoda,Cymothoidae) an unusual parasite (commensal?) of the buccal cavities of piranhas (Serrasalmus sp.) from Roraima, Brazil. Amazoniana, 10(3):239-248.

THATCHER, V. E.; CARVALHO, M. L. 1988. Artystone minima n. sp. (Isopoda, Cymothoidae) a body cavity parasite of the pencil fish (Nannostomus beckfordi Guenther) from the Brazilian Amazon. Amazoniana, 10(3):255-265.

TRILLES, J. P. 1973. Notes documentaires sur les Isopodes Cymothoadiens parasites de poissons d'eau douce de l'Amérique du Sud. Bull. Mus. Nat. D'Hist. Nat, 3ra. ser No. 114. zool. 88: 239-266, pl. I \& II.

VAN NAME. W. G 1925. The isopods of Kartabo, Bartica district. British Guiana, Zoologica, 6(5):461-503. pl. VII-XXVI. 